\title{
Standardization, ethics and biometric indicators in scientific publication: integrative review
}

\author{
Normatização, ética e indicadores bibliométricos em divulgação científica: revisão integrativa \\ Estándares, ética e indicadores bibliométricos en la difusión científica: revisión integrativa
}

\begin{abstract}
Renata Perfeito Ribeiro'
ORCID: 0000-0002-7821-9980

Patricia Aroni'

ORCID: 0000-0001-5092-2714
\end{abstract}

'Universidade Estadual de Londrina. Londrina, Paraná, Brazil.

How to cite this article:

Ribeiro RP, Aroni P. Standardization, ethics and

biometric indicators in scientific publication: integrative review. Rev Bras Enferm. 2019;72(6):1723-9. doi: http://dx.doi.org/10.1590/0034-7167-2018-0283

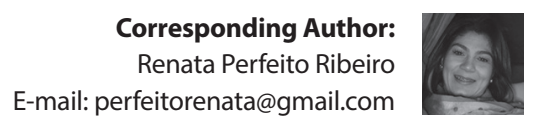

Submission: 09-25-2018 Approval: 01-17-2019

\begin{abstract}
Objective: to analyze scientific evidence available in health literature on ethics, standardization and biometric indicators. Method: an integrative review carried out in August 2016, on the databases: National Library of Medicine, Literatura Latino-Americana e do Caribe em Ciências da Saúde (Latin-American and Caribbean Literature on Health Sciences), and on the library Scientific Electronic Library Online. The review included primary articles on: ethics, standardization and biometric indicators, in Portuguese, English, or Spanish; and excluded studies that were not found as full texts, as well as opinions, commentary, reviews, theses, and dissertations. For the evaluation of the articles, it was used evidence levels from one to five. Results: eight articles were included, with scientific evidence levels 4 and 5: scientific productivism, production evaluation systems, internationalization, impact factor, classification of journals, and adequate and inadequate practices for publication. Conclusion: it was verified the need for publications with higher evidence levels so that Brazilian journals can follow international standards dealing with research ethics.

Descriptors: Knowledge; Communication; Research; Periodicals; Journal Article.
\end{abstract}

\section{RESUMO}

Objetivo: analisar evidências científicas disponíveis na literatura da área da saúde sobre ética, normatização e indicadores bibliométricos. Método: revisão integrativa realizada em agosto de 2016, nas bases de dados: National Library of Medicine, Literatura LatinoAmeticana e do Caribe em Ciências da Saúde e a biblioteca Scientific Electronic Library Online. Foram incluídos artigos primários sobre: ética, normatização e indicadores bibliométricos, em português, inglês ou espanhol, e excluídos estudos que não foram encontrados na íntegra, opiniões, comentários, revisões, teses e dissertações. Foram utilizados níveis de evidência de um a cinco para avaliação dos artigos. Resultados: foram incluídos oito artigos com nível de evidência científica 4 e 5: produtivismo científico, sistemas de avaliação da produção, internacionalização, fator de impacto, classificação de periódicos e práticas adequadas e inadequadas para publicação. Conclusão: Observouse a necessidade de publicações com maiores níveis de evidência e atenção para que os periódicos nacionais sigam padrões internacionais que abordem ética em pesquisa. Descritores: Conhecimento; Comunicação; Pesquisa; Periódicos; Artigo de Revista.

\section{RESUMEN}

Objetivo: analizar las evidencias científicas disponibles en la literatura del área de la salud sobre ética, estándares e indicadores bibliométricos. Método: revisión integrativa realizada en agosto de 2016, en las bases de datos National Library of Mediciney Literatura Latinoamericana y del Caribe en Ciencias de la Salud, y en la biblioteca Scientific Electronic Library Online. Se incluyeron artículos primarios sobre ética, estándares e indicadores bibliométricos, en portugués, inglés o español; y se excluyeron estudios que no se encontraron en su totalidad, opiniones, notas, revisiones, tesis y disertaciones. Se utilizaron los niveles de evidencia de uno a cinco en la evaluación de los artículos. Resultados: se incluyeron ocho artículos con nivel de evidencia científica 4 y 5 : el productivismo científico, los sistemas de evaluación de la producción, la internacionalización, el factor de impacto, la clasificación de periódicos y las prácticas adecuadas e inadecuadas para la publicación. Conclusión: se observó la necesidad de publicaciones con mayores niveles de evidencia y atención para que las revistas nacionales sigan los estándares internacionales que aborden la ética en investigación.

Descriptores: Conocimiento; Comunicación; Investigación; Periódicos; Artículo de Revista. 


\section{INTRODUCTION}

Research is the key to present scientific articles to publish them and to promote changes in practice. It is in the academic environment that researches happen, being that the proper and adequate environment for publications, with the need for sharing what was discovered in new researches or confirmed from previous researches ${ }^{(1)}$. Thus, researches promote one of their primary objectives, which is the diffusion of acquired knowledge $\mathrm{e}^{(2-3)}$.

Students and future researches are encouraged to develop and to participate in scientific investigation networks, along with their advisers or supervisors. This partnership occurs through the collaboration in performing studies ${ }^{(4)}$ and by the participation in research groups, coordinated by advisors or supervisors.

To perform a research and write scientific articles is not an easy task, as one can see by the obligations of professors as researchers, both didactic and administrative ones, in the institutions they are affiliated to. Another aspect comprises students' inexperience, who still lack the necessary knowledge to write and publish articles, therefore, they need to be guided. This task demands dedication, time and motivation by all involved researchers ${ }^{(5)}$.

Thus, the rejection of an article may affect them, discouraging the continuity in researches, besides affecting the researchers to the point of not writing more scientific articles ${ }^{(6)}$. When these difficulties are overcome, good researchers arise, improving their skills of writing and carrying out good researches, publishing them in well-qualified journals that perform their evaluations in the peer review format.

The most important thing for researchers, must be the care taken in all the phases of a research and the certainty that their findings are published for the knowledge and growth of the scientific community of that area. This relation brings recognition to researchers through mentions of their articles and the increase of the impact factor (IF) conferred to them and their research groups.

For that, it is necessary for the researchers to take an ethical posture and to practice policies that inhibit ethic problems related to their publications. The number of publications of a researcher is the basis for many evaluations of higher education institutions, such as the progression in academic career, receiving support for performing and continuing researches, scores for master and $\mathrm{PhD}$ programs in which these researchers are inserted, besides receiving scholarships for undergraduate researches.

This factors create demands for the number of publications that researchers must publish, causing an academic productivism $^{(7)}$, which may lead to the production of low quality scientific articles and to the "salami science".

Article authors and editors of scientific journals must look for good practices in publication, with the protection and precision of research results, publication of negative data, as well as the ones contrary to the hypothesis determined in the beginning of the research, and the declaration of financing sources and conflicts of interest ${ }^{(8)}$. For these ethical aspects related to researches, scientific journals must adopt the recommendations of the Committee on Publications Ethics (COPE) ${ }^{(9)}$.

Facing the need to publish at any cost, ethical problems may arise, as the aforementioned ones: "salami science", plagiarism, self-citations, duplicate publications, authorship issues and even ghostwriting (articles written by other people) ${ }^{(10)}$.
Besides ethical matters, there is also the matter of the evaluation in scientific journals, which is usually performed by the FI published by the Journal Citation Report (JCR) and by the SJR indicator of the Scrimago Journal Ranking \& Country Rank ${ }^{(11)}$. These evaluations use the knowledge of bibliometrics science, which uses mathematics and statistics to investigate the process of scientific publication ${ }^{(12)}$, presenting public portals including scientific journals ${ }^{(13)}$.

Therefore, there is a dilemma on the need for publications, but little is discussed in the health area on publication ethics, standardization and biometric indicators in scientific editing.

\section{OBJECTIVE}

To analyze scientific evidence available in health literature on ethics, standardization, and biometric indicators.

\section{METHOD}

This integrative review study aims to summarize research results found in literature, looking for evidences of decision-making based on the evinced scientific results, besides demonstrating gaps in scientific knowledge that are yet to be researched ${ }^{(14)}$.

An integrative review must follow some phases: the first one must be identifying the theme and selecting the hypothesis or research question $^{(14)}$. In this review, the research question was based on the PICO strategy (an acronym for patient, intervention, comparison, outcomes) ${ }^{(15)}$ and presented as: "Which scientific evidence are available in health journals that portray publication ethics, standardization, and biometric indicators?".

The following phase covered: the determination of study inclusion and exclusion criteria, selection of databases, descriptors to be used, and the extraction of data from articles ${ }^{(14)}$. Inclusion criteria used were: primary articles dealing with the following subjects: editing ethics, standardization of scientific articles, and biometric indicators; written in Portuguese, English, or Spanish. The review excluded studies that were not found as full texts, commentary, reviews, theses, and dissertations. Data collection was performed in August 2016.

Databases selected were: National Library of Medicine (PubMed), Literatura Latino-Americana e do Caribe em Ciências da Saúde (LILACS - Latin-American and Caribbean Literature on Health Sciences), and the library Scientific Electronic Library OnLine (SciELO). We have chosen to include SciELO as the site for primary article search due to its significance for the investigated theme. For the database PubMed, the following Medical Subject Heading (MeSh Database) descriptors were used: knowledge, journal, article, research, publication, communication, and periodicals, used with the help of the Boolean OR for the search in this database (knowledge OR journal OR article OR research OR publication OR communication OR periodicals). For the LILACS database and the SciELO library, it was used the Descriptors in Health Sciences (DeCS): research, journal articles, knowledge, editorial characteristics, communication, and editing. For the search, these descriptors were placed with the help of the Boolean OR (research OR journal articles OR knowledge OR editorial characteristics OR communication OR editing).

For the selection of the articles included in this review, we used the I significance test ${ }^{(16-17)}$, which consists on a list of questions 
answered by to researchers independently ${ }^{(16,18)}$, which had items for the evaluation of article inclusion or exclusion.

The third phase of an integrative review consists on cataloguing relevant information for the extraction of data from the selected studies $^{(14)}$. Thus, the II significance test was used $^{(16-17)}$ for extraction significant data for article inclusion and exclusion, with new questions that aimed to describe the information needed to answer this research's question. This phase was also carried out independently by the researchers ${ }^{(16,18)}$

In figure 1, the flowchart used for selecting the articles used in this study is shown

In the fourth phase, the evaluation of the articles included in the review was carried out, which consisted on analyzing it critically so to collect relevant information from each article and to also determine the level of evidence through the evaluation of the methodology employed for each one of them ${ }^{(14)}$.

In this review, the study's question was directed towards the investigation of the etiology in health area. Thus, the level of evidence in the selected articles was determined from one to five, as it follows: level 1 consists on a synthesis of cohort or case-control studies, level 2 on a single cohort or casecontrol study, level 3 on meta-synthesis or synthesis of descriptive studies, level 4 on a descriptive or qualitative study, and level 5 on specialists' opinion ${ }^{(15)}$.

In the fifth phase, the integrative review consisted on result interpretation. At this moment, data evaluation and analysis occurred, clarifying the evidences found and the gaps in knowledge for the performance of further researches ${ }^{(14)}$. These findings will be presented in the sections Results and Discussion.

In the sixth and last phase of the integrative review, the scientific findings of this research are presented, which consisted on writing and publishing the scientific article ${ }^{(14)}$, in which the findings must be presented to the scientific community so that changes in practice can be done and researchers can look for the gaps to carry out new researches, as is the case of this article.

\section{RESULTS}

The articles included in this review, regarding their publication dates, search site, authors, type of studies, objectives and main results, are shown in Chart 1.

Among the articles selected, it was verified that two had authors with formations outside the health area ${ }^{(10,19)}$, however, the subjects approached covered publications in public health ${ }^{(19)}$ and ethics in publications of pharmaceutical industries' articles ${ }^{(10)}$.

Chart 1 - Identification of selected articles according to their publication year, search site, authors, type of study, level of evidence, objectives and main results, Londrina, Paraná, Brazil, 2016

\begin{tabular}{|l|l|l|l|}
\hline $\begin{array}{l}\text { Year/ } \\
\text { Search site }\end{array}$ & $\begin{array}{l}\text { Authors/Type of } \\
\text { study/Level of } \\
\text { Evidence }\end{array}$ & Objective & Main Results \\
\hline $\begin{array}{l}2016 \\
\text { PubMed }\end{array}$ & $\begin{array}{l}\text { Gasparyan AY, } \\
\text { Yessirkepov M, } \\
\text { Voronov AA, Gorin SV, } \\
\text { Koroleva AM, Kitas GD. } \\
\text { Specialist opinion } \\
\text { Level of evidence: } 5\end{array}$ & $\begin{array}{l}\text { To raise awareness for all interested parts on } \\
\text { scientific communication of ethical matters } \\
\text { emerging in journal editing and publishing } \\
\text { and to begin a campaign for the update and } \\
\text { support for related institutions. }\end{array}$ & $\begin{array}{l}\text { The registers of global bibliographical services, such } \\
\text { as Scopus and Web of Science, must evaluate its } \\
\text { indexed sources regularly and remove from the list } \\
\text { those that violate stablished standards for scientific } \\
\text { research and publication ethics, as well as to inhibit } \\
\text { non-ethical citation practices. }\end{array}$ \\
\hline $\begin{array}{l}2015 \\
\text { SciELO }\end{array}$ & $\begin{array}{l}\text { Packer AL. } \\
\text { Specialist opinion } \\
\text { Level of evidence: } 5\end{array}$ & $\begin{array}{l}\text { To base the debate on journal } \\
\text { internationalization and proper valuation. }\end{array}$ & $\begin{array}{l}\text { To debate scientific productivism, evaluation and } \\
\text { internationalization systems. } \\
\text { To develop advance policies. } \\
\text { Balance between national and international publications. }\end{array}$ \\
\hline $\begin{array}{l}2014 \\
\text { SciELO }\end{array}$ & $\begin{array}{l}\text { Santos LG, Costa e } \\
\text { Fonseca AC, Bica CG. } \\
\text { Descriptive study } \\
\text { Level of evidence: } 4\end{array}$ & $\begin{array}{l}\text { To analyze ethical standards adopted by scientific } \\
\text { journals. To design a ethical demand score to assess } \\
\text { applicable criteria for ethics in scientific publication, } \\
\text { besides assessing the impact factor on ethical } \\
\text { demands for the publication in these journals. }\end{array}$ & $\begin{array}{l}\text { Weak correlation, with no statistical significance, } \\
\text { between the values of impact factor and the ethical } \\
\text { demand score. }\end{array}$ \\
\hline
\end{tabular}




\begin{tabular}{|c|c|c|c|}
\hline $\begin{array}{l}\text { Year/ } \\
\text { Search site }\end{array}$ & $\begin{array}{l}\text { Authors/Type of } \\
\text { study/Level of } \\
\text { Evidence }\end{array}$ & Objective & Main Results \\
\hline $\begin{array}{l}2014 \\
\text { PubMed }\end{array}$ & $\begin{array}{l}\text { Moseley ET, Hsu DJ, } \\
\text { Stone DJ, Celi LA. } \\
\text { Specialist opinion } \\
\text { Level of evidence: } 5\end{array}$ & $\begin{array}{l}\text { To widen the concept of data open to the } \\
\text { culture of the scientific research community. }\end{array}$ & $\begin{array}{l}\text { Some factors, such as publication transparency } \\
\text { cooperation among investigators; investment } \\
\text { decentralization; funding; grants; and scientific } \\
\text { discovery's credit, may bring forth a culture of } \\
\text { collaboration and shared data, as well as a more } \\
\text { complete and precise presentation of scientific } \\
\text { results. }\end{array}$ \\
\hline $\begin{array}{l}2010 \\
\text { PubMed }\end{array}$ & $\begin{array}{l}\text { Sismondo S, Doucet M. } \\
\text { Specialist opinion } \\
\text { Level of evidence: } 5\end{array}$ & $\begin{array}{l}\text { To reinforce and expand publication ethics as } \\
\text { an important concern area for bioethics. }\end{array}$ & $\begin{array}{l}\text { To ensure ethical researches and guarantee that } \\
\text { ghostwriting would not be used, the best option } \\
\text { would be not publishing commercially sponsored } \\
\text { articles. }\end{array}$ \\
\hline $\begin{array}{l}2006 \\
\text { SciELO }\end{array}$ & $\begin{array}{l}\text { Golloghy L, Momen } \mathrm{H} \text {. } \\
\text { Specialist opinion } \\
\text { Level of evidence: } 5\end{array}$ & $\begin{array}{l}\text { To present definitions and means through } \\
\text { which ethical issues may be documented. }\end{array}$ & $\begin{array}{l}\text { Editors must improve publication practices, becoming } \\
\text { familiar to guidelines on research ethics, having } \\
\text { the possibility of being warned by their peers, and } \\
\text { promote adequate practices on publications. }\end{array}$ \\
\hline $\begin{array}{l}2005 \\
\text { PubMed }\end{array}$ & $\begin{array}{l}\text { Freda MC, Kearney M. } \\
\text { Descriptive Study } \\
\text { Level of evidence: } 4\end{array}$ & $\begin{array}{l}\text { To describe editorial practices of nursing editors } \\
\text { and to verify their opinions on efficient editorial } \\
\text { practices. }\end{array}$ & $\begin{array}{l}\text { Editors learn the editing task in many ways, } 94 \% \text { on } \\
\text { daily work, } 46 \% \text { along with an experienced editor, } \\
\text { and } 43 \% \text { along with other editors. Nurse editors may } \\
\text { consider both careers distinct: the career editor of } \\
\text { journals or newsletters and the career of an academic } \\
\text { journal editor. }\end{array}$ \\
\hline $\begin{array}{l}2003 \\
\text { PubMed }\end{array}$ & $\begin{array}{l}\text { Porta M, Copete JL, } \\
\text { Fernandez E, Alguacil } \\
\text { J, Murillo J. } \\
\text { Specialist opinion } \\
\text { Level of evidence: } 5\end{array}$ & $\begin{array}{l}\text { Theoretical article dealing with the impact } \\
\text { factor of scientific journals. }\end{array}$ & $\begin{array}{l}\text { It ponders that the number of citations received } \\
\text { is better than the impact factor to assess the } \\
\text { bibliography of a researcher. }\end{array}$ \\
\hline
\end{tabular}

\section{DISCUSSION}

As the main conclusions of the articles inserted in this review, we have scientific productivism ${ }^{(19-20)}$, the evaluation systems in relation to the productions by researchers/journals ${ }^{(19,21-24)}$, adequate/inadequate practices for publication ${ }^{(10,20-23,25)}$, the $\mathrm{IF}^{(22,25)}$ used to classify periodicals, and the internationalization of national journals ${ }^{(19)}$.

The evaluations regarding the researchers' scientific production are based on the number of publications in a certain period, added to the qualification of the chosen journal ${ }^{(26)}$. This way of evaluating created academic productivism, which comprises an unrestrained search for article publication by the scientific community. Instead of using productivity as the achievement of goals, one could use the efficiency of each professor individually, assessing quality, social impact, and the team of researchers involved in the researches performed, including undergraduate scholarship students, master students, PhD students, and postdoctorate students, as well as researchers from other national and international institutions.

Academic productivism creates improper conduct in research publication, among them, there is the "salami science", which creates poor articles, with no contributions to the advancement of scientific knowledge in the area, being those some of the reasons for refusing articles when they are submitted to wellqualified journals.

This subject is being approached with researchers and postgraduate students. It is known that when a research is fully published, avoiding its division, it will be more complete and have higher quality, causing the researchers to receive more citations for said research, thus increasing their IF.

This practice is not the most adequate way to enhance academic knowledge, since the pressure to publish unrestrainedly, at any means, distorts the objectives of a publication, which must be always connected to true research results and to fully performed studies $^{(7)}$. Kuhlman ${ }^{(7)}$ also suggests the word publicationism for the practice of quick and fragmented publications of articles that do not contribute for the knowledge and that have as their sole reason to increase production indicators, interfering with the researchers' activities.

The health of professors working on post-graduate program has also been affected by academic productivism, with the work overload they have been facing to fulfill their goals with high demands ${ }^{(27)}$.

Undoubtedly, this issue must be discussed so to favor other evaluation means, evincing the disadvantages imposed by the evaluation systems and developing private policies for advancements in article quality ${ }^{(19)}$.

Ethical dilemma constitute another topic mentioned by the articles included in this review. Among them is the research "salami science", which, besides being present in the academic productivism, is an ethical dilemma related to plagiarism and self-plagiarism, article repetition, data invention, and multiple authorship.

This kind of ethical problem seems related to some researchers' hopelessness regarding their work type, and it may be caused 
by the certainty of impunity or even, as aforementioned, by the need for publishing at any cost, and by the proliferation of low quality journals, which are fragile, little professionalized and badly managed, and do not carry out serious judgements for the articles to be published. Therefore, ways for detecting, monitoring and promoting research ethics must be designed ${ }^{(26)}$.

Article refusals may also favor ethical problems, since authors need quick publications for the creation of indicators and, thus, use publication strategies that will enable it. The questionable quality of articles is one of the biggest reasons for refusing to publish them, but other issues also lead authors to give up their publications, among them are overly long processes for article review and the lack of feedback by the evaluators ${ }^{(28)}$.

Another very common ethical issue is the criteria used to include authors in the articles. Authors affirm that, in the stablished criteria, some questions must be present, such as: substantial contributions that authors have given to the article, data interpretation, writing or reviewing the article, and approving the final version to be published ${ }^{(23)}$.

Among the most frequent problems, it is possible to observe the inclusion of authors who did not contribute and the exclusion of authors who have truly participated in the production of the article, which happens always in the intend of increasing the number of publications ${ }^{(23)}$. Regarding this, the International Committee of Medical Journal Editors (ICMJE) has determined how the co-authorship policy must be approached ${ }^{(29)}$.

Measures should be taken by journal editors in order to inhibit this practice: mailing to authors before the publication and discussion on the matter ${ }^{(23)}$. In this sense, some scientific journals are already using strategies to reduce abuses, such as: describing the contribution of each author for the article, using anti-plagiarism tools, and indications by the COPE, besides prohibiting publications of a same work in more than one scientific journal, and adopting evaluations performed by ad hoc referees.

Among the disadvantages of adopting non-ethical practices in publications, regarding the presentation of studies in more than one journal, there is waste of time by reviewers and editors, consumption of journal resources, and lack of academic benefits. In relation to "salami science" publications, one can mention plagiarism, data duplication, and fragmentation of scientific knowledge ${ }^{(23)}$.

Also regarding research integrity, COPE, stablished in the Second Conference on Research Integrity, in Singapore, determines that guidelines must be adopted as ethical norms for the publication of scientific articles ${ }^{(9)}$, affirming that the invention and falsification of research results, lack of author acknowledgement, plagiarism and self-plagiarism, publication duplication and lack of appreciation by the Committee of Research Ethics are severe violations. Thus, authors must respond to these infractions legally.

Regarding the indexation, in Brazil, there are about 400 journals indexed on SciELO, Web of Science (WoS), and Scopus, indicating an increase in the number of researchers and post-graduate $\operatorname{programs}^{(30)}$.

SciELO's strict quality control for journals to enter and remain in its data library is compatible to international bibliometric indexes, but it reduces the possibilities of disseminating knowledge by disregarding the indexation of books ${ }^{(19)}$.
Another important matter is not considering publications in journals from different areas from the author's, however, received mentions and indicators take into account all articles, regardless of the journal's area ${ }^{(19)}$.

For journals to enter and remain in SciELO, the program has been promoting professionalization, internationalization, and financial sustainability as determining factors for indexation. The intent is to increase the indexation of articles written in English and of manuscripts evaluated by editorial boards composed by foreign research members ${ }^{(19)}$.

The way of evaluating for the indexation and maintenance of journals in SciELO is different for each knowledge area, presenting more or less requirements for each item needed to enter this database, which is one of the qualities of the program, since each knowledge area covers a singular way of working ${ }^{(26)}$.

The IF, determined by agencies, is a way of classifying indexed journals that has nothing to do with the demands of each journal ${ }^{(22)}$.

The Qualis-Capes system is responsible for classifying thousands of journals, being set as the main instance for the qualification of researches performed within post-graduate programs ${ }^{(30)}$. In this system, which was created to assess post-graduate programs, only journals that have shown up among publications from programs in the evaluation period (at each four years) are ranked. Besides the main criteria to be qualified in Qualis A, the IF (JCR) and $H$ Index (SJR) have been used. It is important to highlight that these metrics, when used isolated as a bibliometric quality index, are criticized for their total hegemony.

Limitations in relations to the use of bibliometric indexes as evaluators of the scientific community are related to the fact that researchers are only recognized when they have high bibliometric indexes, besides it being considered a way of evaluating researches by candidates of public tenders and for progression in academic career. This tool is incomplete when used for evaluation.

Bibliometric indexes calculate indicators or metrics about the distribution of documents and mentions given and received, through the analysis of documents indexed in databases ${ }^{(30)}$.

Results are ranked by the following searchers: JCR (based on mentions collected from WoS), SJR (based on mentions from Scopus, by its own name), and Google Metrics (based on Google Scholar, presenting the $\mathrm{H}$ index $)^{(30)}$.

SciELO, by operating on Web of Science databases, thus becoming Scielo Citation Index, has the possibility of counting the mentions of the indexed articles ${ }^{(30)}$.

The discussion in this study brings forth suggestions for quality improvement in researches developed in post-graduate programs: to make the process of evaluating articles in journals quicker, to recruit better qualified evaluators, to create a network of researchers with knowledge and daily dedication to research and update ${ }^{(28)}$, besides the insertion of PhD students in this process, providing courses in stricto sensu post-graduation that can qualify them for this task.

The evaluated articles have presented evidence levels classified as $5^{(10,19,21,23-25)}$ and $4^{(20,22)}$, which demonstrated that this matter has been discussed by authors with the intent of reflecting on these themes, exposing their opinions. On the other hand, two articles have used the descriptive method to discuss ethic scores in research and the editors' work. It can be noticed that 
these subjects are discussed in norms available for authors and editors to follow.

\section{Study limitations}

This study has presented as its limitation the exclusion of nine articles, since they were not fully available. It can be supposed that the availability of these studies and their further reading could present the matters in different panoramas.

\section{Contributions to the nursing area}

This study has contributed to the nursing area by demonstrating the need for publications with higher levels of evidence, besides urging for national journals to follow international standards dealing with research ethics. Likewise, it evinces the need for policies that inhibit academic productivism, avoiding bibliometric indexes as researcher evaluators, but teaching future researchers to adopt ethical practices in their researchers, so they may use good practices in their productions.

\section{CONCLUSION}

This study had, as its main scientific evidences, articles available in literature with levels of evidence 4 and 5 , which deal with ethics, standardization and bibliometric indicators in editing. The main subjects approached by the articles were academic productivism, systems of evaluating researcher's scientific production, journal internationalization, IF, and adequate and inadequate publication practices.

\section{REFERENCES}

1. Glasper EA, Peate I. Writing for publication: science and healthcare journals. Br J Nurs. 2013;22(16):964-8. doi: 10.12968/bjon.2013.22.16.964

2. Glasper EA, Schilling J. Writing for publication in issues in comprehensive pediatric nursing. Issues Compr Pediatr Nurs. 2013;36(3):178-87. doi: 10.3109/01460862.2013.820610

3. Latham CL, Ahern N. Professional writing in nursing education: creating an academic-community writing center. J Nurs Educ. 2013;52(11):615-20. doi: 10.3928/01484834-20131014-02

4. Azer SA, Dupras DM, Azer S. Writing for publication in medical education in high impact journals. Eur Rev Med Pharmacol Sci [Internet]. 2014 [cited 2017 Jul 10];18(19):2966-81. Available from: https://www.europeanreview.org/wp/wp-content/uploads/2966-2981.pdf

5. Morton PG. Publishing in professional journals, part I: getting started. AACN Adv Crit Care. 2013;24(2):162-8. doi: 10.1097/ $\mathrm{NCl} .0 \mathrm{~b} 013 \mathrm{e} 318285 \mathrm{db} 7 \mathrm{c}$

6. DiPiro JT. Acceptance and rejection of manuscripts for publication in the American Journal of Pharmaceutical Education. Am J Pharm Educ. 2013;77(4):66. doi: 10.5688/ajpe77466

7. Kuhlman Jr M. Produtivismo acadêmico, publicação em periódicos e qualidade das pesquisas. Cad Pesqui. 2015;45(158):838-55. doi: http:// dx.doi.org/10.1590/198053143597

8. World Medical Association. World Medical Association Declaration of Helsinki: ethical principles for medical research involving human subjects [Internet]. Bull World Health Organ [Internet]. 2001 [cited 2017 Jun 28];79(4):373-74. Available from: https://www.who.int/bulletin/ archives/79\%284\%29373.pdf

9. Committee on Publication Ethics (COPE). International standards for editors and authors [Internet]. Hampshire: COPE; 2012 [cited 2017 May 10]. Available from: https://publicationethics.org/resources/international-standards-for-editors-and-authors

10. Sismondo S, Doucet M. Publication ethics and the ghost management of medical publication. Bioethics. 2010;24(6):273-83. doi: $10.1111 / j .1467-8519.2008 .01702 . x$

11. Valero JS, Cabo VJ, Castiel LD. A iniciativa Open Access no acesso à informação técnico-científica nas Ciências da Saúde. RECIIS. 2007;1(1):1926. doi: 10.3395/reciis.v1i1.50en

12. Bufrem L, Prates Y. O saber científico registrado e as práticas de mensuração da informação. Ci Inf. 2005;34(2):9-25. doi: 10.1590/ S0100-19652005000200002

13. Scimago Journal \& Country Rank (SJR). International Science Rankings [Internet]. 2017 [cited 2017 Jun 21]. Available from: http://www. scimagojr.com/countryrank.php

14. Mendes KDS, Silveira RCCP, Galvão CM. Revisão integrativa: método de pesquisa para a incorporação de evidências na saúde e na enfermagem. Texto Contexto Enferm. 2008;17(4):758-64. doi: 10.1590/S0104-07072008000400018

15. Fineout-Overholt E, Stillwell SB. Asking compelling, clinical questions. In: Melnyk BM, Fineout-Overholt E, editors. Evidence-based practice in nursing and healthcare: a guide to best practice. Philadelphia: Lippincot Williams \& Wilkins; 2011. p. 25-39.

16. McDonald S, Crumley E, Eisinga A, Villanueva E. Search strategies to identify reports of randomized trials in Medline: protocol for a Cochrane review. Oxford: The Cochrane Library; 2006.

17. Atallah NA, Castro AA. Revisão sistemática da literatura e metanálise: a melhor forma de evidência para a tomada de decisão em saúde e a maneira mais rápida de atualização terapêutica. São Paulo: Lemos-Editorial; 1998. Evidências para melhores decisões clínicas; p. 20-8.

18. Muñoz SIS, Takayanagui AMM, Santos CB, Sanchez-Sweatman O. Revisão sistemática de literatura e metanálise: noções básicas sobre seu 
desenho, interpretação e aplicação na área da saúde [Internet]. In.: Anais do 80 Simpósio Brasileiro de Comunicação em Enfermagem; 2002; Ribeirão Preto, Brasil. Ribeirão Preto: Universidade de São Paulo; 2002 [cited 2017 Jul 12]. Available from: http://www.proceedings.scielo.br/ $\mathrm{pdf} / \mathrm{sibracen} / \mathrm{n} 8 \mathrm{v} 2 / \mathrm{v} 2 \mathrm{a} 074 . \mathrm{pdf}$

19. Packer AL. Indicators of national focus of the research published by Public Health journals edited in Brazil. Ciênc Saúde Colet. 2015;20(7):1983-95. doi: http://dx.doi.org/10.1590/1413-81232015207.07122015

20. Freda MC, Kearney M. An international survey of nurse editors' roles and practices. J Nurs Scholarsh. 2005;37(1):87-94. doi: $10.1111 / j .1547-5069.2005 .00006 . x$

21. Gasparyan AY, Yessirkepov M, Voronov AA, Gorin SV, Koroleva AM, Kitas GD. Statement on publication ethics for editors and publishers. J Korean Med Sci. 2016;31(9):1351-4. doi: 10.3346/jkms.2016.31.9.1351

22. Santos LG, Costa e Fonseca AC, Bica CG. Ethics Requirement Score: new tool for evaluating ethics in publications. Einstein. 2014;12(4):40512. doi: 10.1590/S1679-45082014AO3001

23. Gollogly L, Momen H. Ethical dilemmas in scientific publication: pitfalls and solution for editors. Rev Saúde Pública. 2006;40(N. Esp.):24-9. doi: 10.1590/S0034-89102006000400004

24. Porta M, Copete JL, Fernandez E, Alguacil J, Murillo J. Mixing journal, article, and author citations, and other pitfalls in the bibliographic impact factor. Cad Saúde Publica. 2003;19(6):1847-62. doi: 10.1590/S0102-311X2003000600030

25. Moseley ET, Hsu DJ, Stone DJ, Celi LA. Beyond open big data: addressing unreliable research. J Med Internet Res. 2014;16(11):e259. doi: 10.2196/jmir.3871

26. Rego TC. Productivism, research and scholarly communication: between poison and medicine. Educ Pesqui. 2014;40(2):325-45 doi: 10.1590/ S1517-97022014061843

27. Borsoi ICF. Trabalho e produtivismo: saúde e modo de vida de docentes de instituições públicas de Ensino Superior. Cad Psicol Soc Trab. 2012;15(1):81-100. doi: 10.11606/issn.1981-0490.v15i1p81-100

28. Serra FAR, Fiates GG, Ferreira MP. Publicar é difícil ou faltam competências? O desafio de pesquisar e publicar em revistas científicas na visão de editores e revisores internacionais. RAM, Rev Adm Mackenzie. 2008;9(4):32-55. doi: 10.1590/S1678-69712008000400004

29. Internacional Committee of Medical Journal Editors (ICMJE). Recommendations for the conduct, reporting, editing, and publication of scholarly work in medical journals [Internet]. 2016 [cited 2017 Apr 28]. Available from: http://www.icmje.org/icmje-recommendations.pdf

30. Packer AL. The emergence of journals of Brazil and scenarios for their future. Educ Pesqui. 2014;40(2):301-23. doi: 10.1590/ S1517-97022014061860 